\title{
AGE CHANGES IN GLOMERULAR FILTRATION RATE, EFFEC- TIVE RENAL PLASMA FLOW, AND TUBULAR EXCRETORY CAPACITY IN ADULT MALES
}

\author{
By DEAN F. DAVIES ${ }^{1}$ AND NATHAN W. SHOCK \\ (From the National Heart Institute, National Institutes of Health, Bethesda, Maryland; and \\ the Gerontology Section, Baltimore City Hospitals, Baltimore)
}

(Submitted for publication October 25, 1949; accepted, December 28, 1949)

It has previously been shown that inulin clearance, diodrast clearance, and diodrast $\mathrm{Tm}$ are significantly lower in males between the ages of 60 and 80 years than in males $20-40$ years of age $(1,2)$. The clearance and Tm values commonly used as norms are based on averages calculated from observations made on subjects between the ages of 17 and 68 years (3-5).

The present study was undertaken to evaluate the rate of the age changes in renal functions previously reported.

\section{EXPERIMENTAL METHODS}

Subjects. Seventy males aged 24 to 89 years served as subjects. They were chosen from wards of the Baltimore City Hospitals, the Baltimore City Infirmary (Old People's Home), the Veteran's Hospital, Fort Howard, Maryland, and the house staff of the City Hospitals. All were selected only after thorough history and physical examination which excluded anyone showing the following: (1) recent or remote renal diseases, (2) cerebrovascular accident, (3) coronary artery disease, (4) syphilitic, or (5) rheumatic heart disease, (6) hypertension, (7) any recent alteration in body weight.

At the higher ages, blood pressures were not considered hypertensive unless the diastolic pressure was greater than $90 \mathrm{~mm} . \mathrm{Hg}$, since systolic hypertension with increased pulse pressure may be the result of dilatation and loss of elasticity in the larger arteries, a change commonly associated with aging $(6,7)$. Nevertheless, only two tests were done on patients with systolic pressures greater than $160 \mathrm{~mm} . \mathrm{Hg}$. Patients from acute wards of the Hospital were accepted occasionally but only if they were in the convalescent stages of their disease, afebrile, and had been without medication for several days. Patients from the Tuberculosis Hospital were accepted if ambulatory and sputum-negative for at least six months or as long as they had been hospitalized.

Experimental procedure. The tests were done according to the constant infusion technique of Smith, Goldring and Chasis (5) with a few minor modifications (2). Experimental procedures were performed in the morning under essentially basal conditions but in some cases

1 Present address: Department of Internal Medicine, Washington University School of Medicine, Saint Louis, Mo. milk or fruit was permitted in addition to water. Subjects were hydrated for one to two hours before the test with 600 to $800 \mathrm{cc}$. of water, and $200 \mathrm{cc}$. of water was given at half-hourly intervals during the test. Blood pressure was taken after the subject had been resting in bed at least one-half hour in a semi-reclining position with the head gatch at 15 to 30 degrees. This elevation was maintained throughout the test. Infusion of fluid during equilibration, clearance, and $\mathrm{Tm}$ periods was regulated accurately at $3.0 \mathrm{cc} / \mathrm{min}$. with a tunnel clamp. Four clearance and four $\mathrm{Tm}$ periods of 10 to 14 minutes each were taken according to the method of Smith and associates (5). Blood samples were drawn at the mid-point of each period through a stylet needle maintained in the vein during the experiment. Urine samples were collected by an indwelling catheter, and the bladder was washed with three 50-cc. portions of saline at the close of each period.

Analytical methods. The analytical methods previously described (2) were used except that a Coleman Model 14 Spectrophotometer was substituted for the Model 11. Plasma filtrates, prepared according to Alpert (8), served for the determination of inulin (9) and diodrast (10). Albumin was separated from the plasma according to the method of Kingsley (11), but micro-Kjeldahl determinations of plasma albumin and total protein were made by the method of $\mathrm{Ma}$ and Zuazaga (12). Hematocrit and yeastocrit determinations were made according to Wintrobe (13).

Treatment of the data. Renal clearances were calculated from analyses of blood and urine samples for each period. Average values for the four clearance periods were computed for each subject. Average values for diodrast $\mathrm{Tm}$ were computed from the four Tm periods. All values were reduced to the standard of 1.73 sq.m. surface area. Surface areas of all subjects were estimated from height and weight according to the DuBois formula. Filtration fraction $\frac{\left(\mathrm{Cl}_{I}\right)}{\left(\mathrm{Cl}_{\mathrm{D}}\right)}$, the ratio of inulin clearance to diodrast $\operatorname{Tm} \frac{\left(\mathrm{Cl}_{\mathrm{I}}\right)}{(\mathrm{Tm})}$, and the ratio of diodrast clearance to diodrast $\operatorname{Tm} \frac{\left(\mathrm{Cl}_{\mathrm{D}}\right)}{(\mathrm{Tm})}$ were computed for each subject. Mean values and the standard deviations of the distributions were computed by age decades for all observations.

\section{RESULTS}

Subject characteristics. The subjects tested were free from clinical signs or history of disease states involving the heart or kidneys (Table I). 
This table shows the age, the clinical blood pressure from the case records, and the diagnosis and convalescent state of all subjects tested.

Reliability of measurements. The standard errors of measurement for the tests made were as follows: inulin clearance, $6.2 \mathrm{cc}$./min.; diodrast clearance, $25.9 \mathrm{cc} . / \mathrm{min}$. ; diodrast $\mathrm{Tm}, 2.0 \mathrm{mg}$. I/ min. (See also Table III, [14].)

Age changes in renal clearance and $T m$. With increasing age there is a progressive diminution in the average inulin clearance, diodrast clearance (Figure 1, $\mathrm{a}$ and $\mathrm{b}$ ), and diodrast Tm (Figure

TABLE I

Clinical diagnoses and clinical blood pressures of subjects

\begin{tabular}{c|c|c|c}
\hline \hline Exp. No. & Age & $\begin{array}{c}\text { Clinical } \\
\text { blood pressure }\end{array}$ & Diagnosis \\
\hline & yrs. & $m m . H g$ & \\
\hline
\end{tabular}

20-29 year age group

\begin{tabular}{r|c|c|l}
\hline $23^{*}$ & 25 & $145 / 88$ & Pneumococcic lobar pneumonia. 11 days afebrile. \\
$30^{*}$ & 27 & $124 / 80$ & Dermatitis venenata. 10 days afebrile. \\
$35^{*}$ & 28 & $112 / 70$ & Lobar pneumonia. 14 days afebrile. \\
81 & 24 & $132 / 76$ & Tuberculosis of lungs, moderately advanced. \\
86 & 24 & $122 / 54$ & Lobar pneumonia; pleurisy; atelectasis. 4 days afebrile. \\
102 & 25 & $95 / 60$ & $\begin{array}{l}\text { Pneumococcic lobar pneumonia. 7 days afebrile. } \\
106\end{array}$ \\
107 & 29 & - & Member of professional staff. \\
108 & 28 & - & Member of professional staff. \\
\hline
\end{tabular}

30-39 year age group

\begin{tabular}{r|l|l|l}
\hline $37^{*}$ & 37 & - & Pneumonia, rt. middle lobe. \\
73 & 38 & $120 / 78$ & Pneumococcic lobar pneumonia; atelectasis. 17 days afebrile. \\
74 & 33 & $130 / 90$ & Bilateral apical pulmonary tuberculosis. \\
76 & 38 & $110 / 68$ & Tuberculosis of lungs; pneumoperitoneum. \\
85 & 37 & $152 / 104 \dagger$ & Moderately advanced tuberculosis. \\
109 & 30 & $\overline{\text { None. }}$ \\
118 & 39 & $150 / 90$ & Spontaneous pneumothorax; pulmonary emphysema. \\
129 & 32 & $\overline{1}$ & $\begin{array}{l}\text { Psychoneurosis. } \\
130\end{array}$ \\
\hline
\end{tabular}

40-49 year age group

\begin{tabular}{|c|c|c|c|}
\hline $\begin{array}{r}6 \\
43 \\
44 \\
46 \\
68 \\
77 \\
82 \\
75 \\
122 \\
123\end{array}$ & $\begin{array}{l}49 \\
44 \\
42 \\
44 \\
46 \\
40 \\
41 \\
49 \\
48 \\
46\end{array}$ & $\begin{array}{l}110 / 80 \\
126 / 90 \\
130 / 80 \\
132 / 88 \\
100 / 70 \\
122 / 82 \\
110 / 65 \\
112 / 70 \\
108 / 64\end{array}$ & $\begin{array}{l}\text { Toxic multiple neuropathy due to ethyl alcohol. } \\
\text { Pulmonary tuberculosis, moderately advanced; toxic amblyopia. } \\
\text { Cerebellar degeneration; etiology unknown. } \\
\text { Asthma; bronchopneumonia. } \\
\text { Toxic multiple neuritis due to alcohol; Korsakov psychosis. } \\
\text { Emphysema, general; bronchiectasis. } \\
\text { Pulmonary tuberculosis with pleural effusion. } \\
\text { Fibroid tuberculosis, arrested; alcoholism; bronchiectasis. } \\
\text { None. } \\
\text { Old osteomyelitis of tibia; healed skull fracture. }\end{array}$ \\
\hline \multicolumn{4}{|r|}{ 50-59 year age group } \\
\hline $\begin{array}{r}50 \\
47 \\
51 \\
53 \\
57 \\
64 \\
66 \\
67 \\
78 \\
79 \\
119\end{array}$ & $\begin{array}{l}53 \\
51 \\
54 \\
59 \\
53 \\
53 \\
52 \\
55 \\
53 \\
52 \\
54\end{array}$ & $\begin{array}{l}110 / 64 \\
120 / 78 \\
110 / 70 \\
110 / 70 \\
120 / 80 \\
130 / 70 \\
120 / 76 \\
118 / 72 \\
129 / 88 \\
\end{array}$ & $\begin{array}{l}\text { Senile cataract; operative anophthalmos. } \\
\text { Left leg amputation for gas gangrene. } \\
\text { Senile psychosis with simple deterioration; emphysema. } \\
\text { Thrombosed hemorrhoid. } \\
\text { None. } \\
\text { Anophthalmos, left. } \\
\text { Chronic alcoholism; old injury, left hip. } \\
\text { Bronchiectasis; hypertrophic arthritis. } \\
\text { Tuberculosis of lungs with left. pneumothorax. } \\
\text { Tuberculosis of lungs, moderately advanced. } \\
\text { Psychoneurosis. }\end{array}$ \\
\hline
\end{tabular}


TABLE I (Continued)

\begin{tabular}{|c|c|c|c|}
\hline Exp. No. & Age & $\begin{array}{l}\text { Clinical } \\
\text { blood preseure }\end{array}$ & Diagnosis \\
\hline & yrs. & $m m . H_{g}$ & \\
\hline \multicolumn{4}{|r|}{ 60-69 year age group } \\
\hline $\begin{array}{r}4^{*} \\
31^{*} \\
58 \\
60 \\
62 \\
72 \\
110 \\
112 \\
114 \\
120\end{array}$ & $\begin{array}{l}61 \\
69 \\
62 \\
66 \\
64 \\
65 \\
66 \\
62 \\
67 \\
68\end{array}$ & $\begin{array}{c}110 / 70 \\
160 / 98 \\
150 / 85 \\
130 / 76 \\
-\overline{130 / 90} \\
\overline{110 / 72} \\
140 / 90 \\
160 / 80\end{array}$ & $\begin{array}{l}\text { Pyohydronephrosis with bilateral hydroureter. } \\
\text { Hydrarthrosis; arthritis of knee. } \\
\text { Blindness, rt. eye, due to methyl alcohol. } \\
\text { Healed duodenal ulcer; fracture of shaft of radius and valve with union. } \\
\text { Traumatic spastic paraplegia. } \\
\text { Post-traumatic cortical atrophy. } \\
\text { Varicose veins. } \\
\text { Syphilis of undiagnosed site; osteoarthritis. } \\
\text { Generalized arteriosclerosis; cerebral arteriosclerosis. } \\
\text { Bilateral indirect inguinal hernia; benign prostatic hypertrophy.ł }\end{array}$ \\
\hline \multicolumn{4}{|r|}{ 70-79 year age group } \\
\hline $13^{*}$ & 77 & $104 / 60$ & $\begin{array}{l}\text { Chronic bronchitis; generalized arteriosclerosis; benign prostatic hypertrophy. } \\
\text { Hydronephrosis, } \text { bilateral. }\end{array}$ \\
\hline $\begin{array}{r}15^{*} \\
25^{*} \\
89 \\
141 \\
143 \\
144 \\
153\end{array}$ & $\begin{array}{l}70 \\
72 \\
72 \\
78 \\
71 \\
74 \\
71\end{array}$ & $\begin{array}{l}-\overline{-} \\
130 / 75 \\
128 / 62 \\
140 / 90 \\
162 / 90 \\
120 / 65\end{array}$ & $\begin{array}{l}\text { Intestinal obstruction; carcinoma of rectum. } \\
\text { Central nervous system syphilis. } \\
\text { Generalized arteriosclerosis; anophthalmus, rt. eye; tuberculosis of lungs. } \\
\text { Generalized arteriosclerosis; senile emphysema. } \\
\text { Generalized arteriosclerosis. } \\
\text { Vocal cord paralysis. } \\
\text { Amputated left leg mid-thigh; chronic infected ulcerated area on rt. leg due to } \\
\text { old injury. }\end{array}$ \\
\hline 200 & 71 & $112 / 58$ & Chronic bronchiectasis; hypertrophic arthritis of spine. \\
\hline
\end{tabular}

80-89 year age group

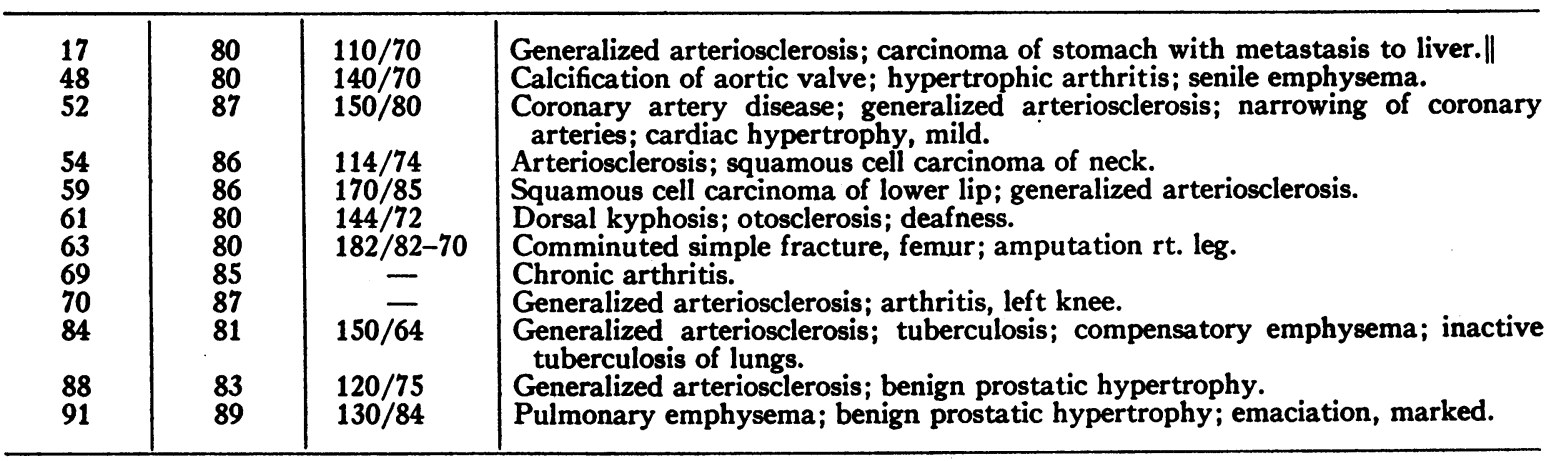

* From original series previously published.

$\dagger$ No cardiac enlargement; $120 / 80$ on physical examination for test.

$\mp$ Discovered at autopsy two years after function test.

Discovered at autopsy three years after function test.

II Discovered at autopsy 14 months after function test.

2a). Table II shows the experimental results and the derived data classified by decades. Although wide individual differences in the effects of age on renal function are apparent few subjects in the oldest group gave values as great as those observed in the youngest group.

The significances of the differences between any two adjacent or non-adjacent decades have been summarized in Figure 3. In Figure 3 mean values for standard inulin and diodrast clearance, diodrast
$\mathrm{Tm}$, and filtration fraction values are tabulated in the borders while age groups by decades are shown in the adjacent triangles. Critical ratios for each decade calculated for each other decade are tabulated in the central squares. ${ }^{2}$ For ex-

2 Critical ratios were calculated by the formula:

$$
\text { C.R. }=\frac{M n_{1}-M n_{2}}{\sigma\left(M_{n_{1}}-M_{n_{2}}\right)}
$$

Values greater than 2.3 are significant at the 5 per cent levels. 

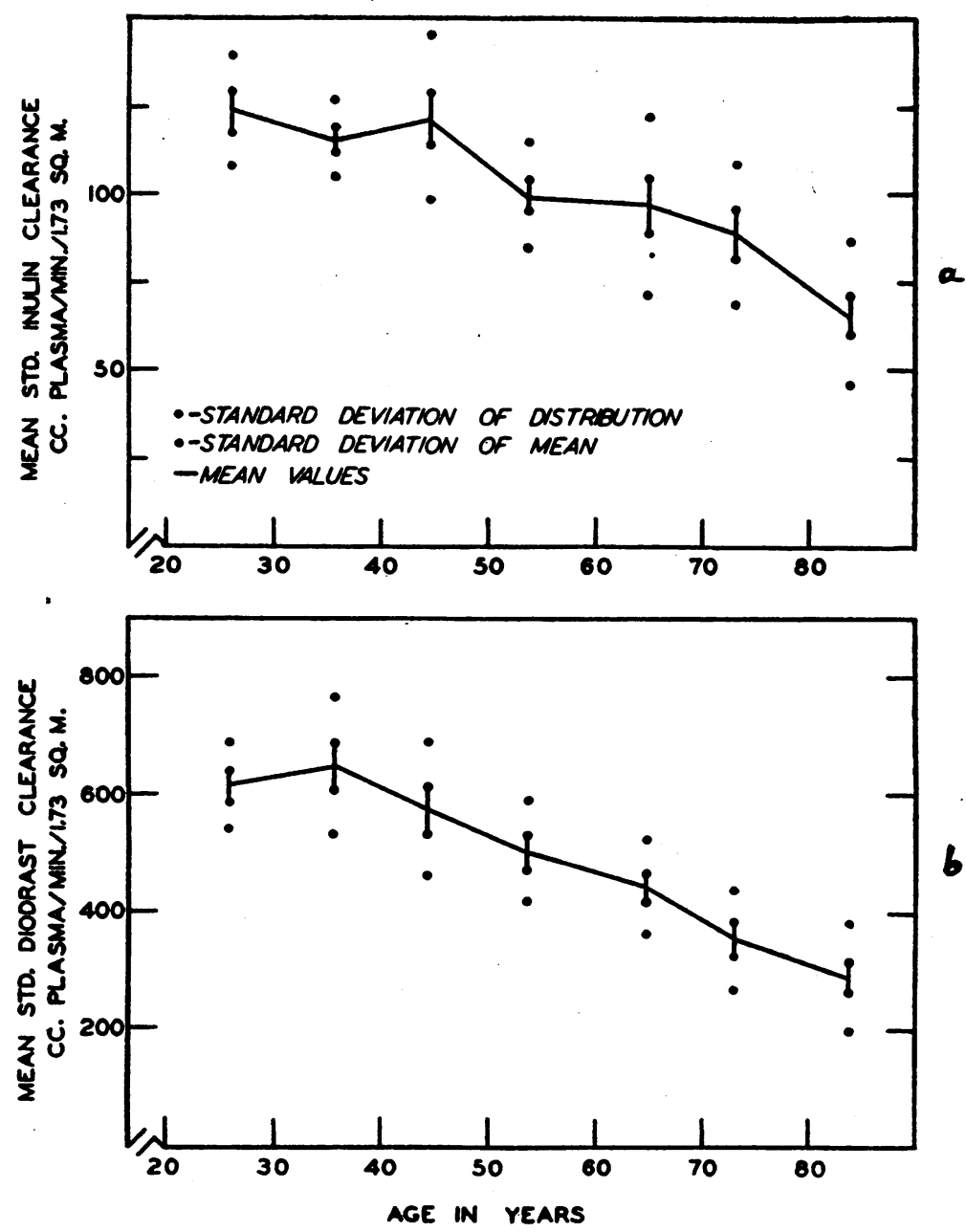

Fig. 1a. Average Change in Standard Inulin Clearance or Glomerular Filtration Rate with Age, cc. Plasma/min./1.73 sq.M. Body Surface Area

b. Average Change in Standard Diodrast Clearance or Effective Renal Plasma Flow with Age, cc. Plasma/min./1.73 sq.m. Body Surface Area

In all figures the vertical lines represent \pm 1 standard deviation of the mean; the circles represent \pm 1 standard deviation of the distribution.

ample, mean effective plasma flows are tabulated in the vertical column at the left of the table. The age is shown in the small triangle to the right of the mean. The critical ratio between the 20 - and 30-year groups is tabulated at the intersection of the two diagonal rows, viz., 0.772 . The critical ratio of the difference between the 20 - and 60 -year groups is found at the intersection of the 20- and 60-year diagonals, viz., 4.85. Glomerular filtration rates are similarly tabulated along the right-hand side of the table. Filtration fractions and maxi- mum tubular excretory capacity are found at the top and bottom of the table respectively. Examination of this figure shows that inulin clearance, diodrast clearance, and diodrast $\mathrm{Tm}$ in general show more significant changes between adjacent decades beyond the age of 40 than in early adult life.

When alternate decades are studied, the significance of the differences is high for all but young adults; that is, significant changes occur over 20 year intervals of time. 
TABLE II

Age changes in renal function

\begin{tabular}{|c|c|c|c|c|c|c|c|c|c|c|}
\hline $\begin{array}{l}(1) \\
\text { Exp. } \\
\text { No. }\end{array}$ & $\begin{array}{l}(2) \\
\text { Age }\end{array}$ & $\begin{array}{c}\text { (3) } \\
\text { Blood } \\
\text { pressure }\end{array}$ & $\begin{array}{l}\text { (4) } \\
\text { Surface } \\
\text { area }\end{array}$ & $\begin{array}{c}\text { (5) } \\
\text { Standard } \\
\text { inulin } \\
\text { clearance }\end{array}$ & $\begin{array}{c}\text { (6) } \\
\text { Standard } \\
\text { diodrast } \\
\text { clearance }\end{array}$ & $\begin{array}{c}\text { (7) } \\
\text { Standard } \\
\text { effective renal } \\
\text { blood flow }\end{array}$ & $\begin{array}{c}(8) \\
\underset{T \text { Ttandard }}{\text { TmD }}\end{array}$ & $\begin{array}{c}\text { (9) } \\
\text { Filtration } \\
\text { fraction }\end{array}$ & $\begin{array}{l}(10) \\
\mathrm{ClD} \\
\mathrm{TmD}\end{array}$ & $\begin{array}{l}(11) \\
\frac{C l_{I}}{T m D}\end{array}$ \\
\hline & yrs. & $m m \cdot H_{8}$ & sq.m. & $\underset{\text { sq.m. }}{c c . / \min . / 1.73}$ & $\underset{\text { sq.m. }}{c c . / \min . / 1.73}$ & $\underset{\text { sq.m. }}{c c . / \min . / 1.73}$ & $\begin{array}{c}\text { mg.I/min./ } \\
1.73 \text { sq.m. }\end{array}$ & per cent & & \\
\hline
\end{tabular}

20-29 Year Age Group

\begin{tabular}{r|l|l|l|l|l|l|l|l|r|r}
\hline 23 & 25 & $118 / 80$ & 2.09 & 128.2 & 724.0 & 1353.0 & 60.74 & 17.7 & 11.90 & 2.11 \\
30 & 27 & $160 / 82$ & 1.75 & 141.5 & 679.2 & 1192.0 & 57.90 & 21.2 & 11.70 & 2.44 \\
35 & 28 & $135 / 85$ & 1.89 & 124.6 & 640.0 & 1019.0 & 58.20 & 19.5 & 13.60 & 2.56 \\
81 & 24 & $122 / 78$ & 1.50 & 101.0 & 480.8 & 858.6 & 49.55 & 21.1 & 9.71 & 2.04 \\
86 & 24 & $132 / 64$ & 1.98 & 145.8 & 673.5 & 1093.3 & 71.11 & 22.2 & 9.50 & 2.06 \\
102 & 25 & $170 / 68$ & 1.96 & 134.4 & 656.2 & 1206.3 & 63.06 & 20.5 & 10.44 & 1.93 \\
106 & 29 & $118 / 84$ & 1.90 & 93.7 & 503.4 & 873.9 & 40.28 & 18.6 & 12.51 & 2.34 \\
107 & 28 & $118 / 80$ & 1.93 & 115.9 & 574.5 & 1022.2 & 43.77 & 20.2 & 13.13 & 2.65 \\
108 & 25 & $138 / 88$ & 1.94 & 119.7 & 590.0 & 1072.7 & 47.09 & 20.1 & 12.53 & 2.55 \\
\hline Mn. & 26.1 & $135 / 79$ & 1.88 & 122.8 & 613.5 & 1076.8 & 54.63 & 20.1 & 11.69 & 2.30 \\
$\sigma_{d}$ & & & 0.182 & 16.4 & 74.56 & 149.71 & 9.49 & 1.29 & 1.39 & 0.25 \\
\hline
\end{tabular}

30-39 Year Age Group

\begin{tabular}{r|l|l|l|l|l|l|l|l|l|l}
\hline 37 & 37 & $140 / 80$ & 1.78 & 124.0 & 804.0 & 1429.0 & 50.43 & 15.8 & 13.60 & 2.56 \\
73 & 38 & $120 / 70$ & 1.69 & 120.4 & 588.8 & 1034.7 & 45.58 & 20.5 & 13.16 & 2.70 \\
74 & 33 & $110 / 85$ & 1.84 & 124.8 & 794.1 & 1492.7 & 63.38 & 15.7 & 12.54 & 1.97 \\
76 & 38 & $112 / 68$ & 1.805 & 125.3 & 518.5 & 1043.2 & 46.58 & 24.2 & 11.14 & 2.70 \\
85 & 37 & $122 / 82$ & 1.58 & 95.6 & 537.3 & 931.2 & 52.34 & 17.8 & 10.27 & 1.84 \\
109 & 30 & $132 / 86$ & 2.01 & 113.3 & 784.9 & 1472.6 & 53.69 & 14.6 & 14.67 & 2.12 \\
118 & 39 & $140 / 88$ & 1.75 & 123.0 & 502.0 & 933.1 & 39.88 & 24.6 & 12.62 & 3.09 \\
129 & 32 & $118 / 79$ & 1.86 & 110.4 & 709.6 & 1309.2 & 66.14 & 15.6 & 11.06 & 1.73 \\
130 & 33 & $120 / 88$ & 1.92 & 98.2 & 604.2 & 985.6 & 40.70 & 16.4 & 15.01 & 2.43 \\
\hline Mn. & 35.2 & $124 / 81$ & 1.80 & 115.0 & 649.3 & 1181.3 & 50.97 & 18.4 & 12.61 & 2.35 \\
$\sigma_{d}$ & & & 0.167 & 10.84 & 117.36 & 226.7 & 8.63 & 3.61 & 1.54 & 0.43 \\
\hline
\end{tabular}

40-49 Year Age Group

\begin{tabular}{r|l|l|l|l|l|l|l|l|r|r}
\hline 6 & 49 & $175 / 90$ & 1.92 & 124.8 & 460.0 & 741.9 & 53.50 & 27.2 & 8.60 & 2.33 \\
43 & 44 & $120 / 85$ & 1.74 & 121.3 & 735.8 & 1226.2 & 56.30 & 16.5 & 13.07 & 2.15 \\
44 & 42 & $126 / 86$ & 1.52 & 93.2 & 447.0 & 758.1 & 37.63 & 20.1 & 11.91 & 2.48 \\
46 & 44 & $124 / 80$ & 1.88 & 135.9 & 686.2 & 1203.4 & 61.10 & 19.8 & 11.28 & 2.24 \\
68 & 46 & $134 / 82$ & 1.52 & 143.6 & 683.9 & 1171.0 & 51.98 & 20.9 & 13.20 & 2.78 \\
77 & 40 & $116 / 75$ & 1.60 & 110.4 & 619.6 & 1251.7 & 62.30 & 17.8 & 9.96 & 1.78 \\
82 & 41 & $112 / 80$ & 1.55 & 162.3 & 654.8 & 1162.9 & 59.82 & 24.8 & 10.82 & 2.73 \\
75 & 49 & $115 / 70$ & 1.80 & 77.2 & 396.0 & 737.4 & 38.08 & 19.5 & 10.57 & 2.07 \\
122 & 48 & $108 / 64$ & 1.69 & 112.2 & 527.5 & 940.2 & 40.83 & 21.3 & 12.93 & 2.75 \\
123 & 46 & $108 / 66$ & 1.60 & 131.0 & 527.2 & 884.5 & 37.52 & 24.9 & 14.10 & 3.49 \\
\hline Mn. & 44.9 & $124 / 78$ & 1.68 & 121.2 & 573.8 & 1007.7 & 49.91 & 21.3 & 11.64 & 2.48 \\
$\sigma_{d}$ & & & 0.164 & 23.31 & 111.63 & 205.6 & 9.81 & 3.2 & 1.64 & 0.458 \\
\hline
\end{tabular}

50-59 Year Age Group

\begin{tabular}{|c|c|c|c|c|c|c|c|c|c|c|}
\hline $\begin{array}{r}50 \\
47 \\
51 \\
53 \\
57 \\
64 \\
66 \\
67 \\
78 \\
79 \\
119\end{array}$ & $\begin{array}{l}\mathbf{5 3} \\
\mathbf{5 1} \\
\mathbf{5 4} \\
\mathbf{5 9} \\
\mathbf{5 3} \\
\mathbf{5 3} \\
\mathbf{5 2} \\
\mathbf{5 5} \\
\mathbf{5 3} \\
\mathbf{5 2} \\
\mathbf{5 4}\end{array}$ & $\begin{array}{l}105 / 58 \\
130 / 80 \\
110 / 70 \\
120 / 67 \\
110 / 70 \\
160 / 85 \\
112 / 70 \\
128 / 72 \\
118 / 72 \\
120 / 74 \\
132 / 82\end{array}$ & $\begin{array}{l}1.69 \\
1.82 \\
1.71 \\
1.69 \\
1.63 \\
1.88 \\
1.72 \\
1.38 \\
1.63 \\
2.01 \\
1.72\end{array}$ & $\begin{array}{r}113.2 \\
101.4 \\
118.9 \\
117.7 \\
89.1 \\
74.3 \\
86.0 \\
87.6 \\
115.9 \\
99.8 \\
88.9\end{array}$ & $\begin{array}{l}587.0 \\
435.5 \\
516.6 \\
616.8 \\
340.7 \\
398.5 \\
587.8 \\
587.3 \\
534.0 \\
465.4 \\
435.3\end{array}$ & $\begin{array}{r}962.2 \\
764.0 \\
906.3 \\
986.8 \\
630.9 \\
653.3 \\
1006.5 \\
873.9 \\
962.1 \\
846.1 \\
749.2\end{array}$ & $\begin{array}{l}42.44 \\
38.60 \\
44.90 \\
45.40 \\
40.72 \\
37.95 \\
55.68 \\
56.91 \\
43.16 \\
51.64 \\
40.95\end{array}$ & $\begin{array}{l}19.4 \\
23.3 \\
23.0 \\
19.1 \\
26.2 \\
18.7 \\
14.6 \\
17.0 \\
21.7 \\
21.5 \\
20.5\end{array}$ & $\begin{array}{r}13.84 \\
11.33 \\
11.52 \\
13.60 \\
8.47 \\
10.48 \\
10.56 \\
10.42 \\
12.42 \\
9.01 \\
10.64\end{array}$ & $\begin{array}{l}2.67 \\
2.64 \\
2.65 \\
2.60 \\
2.21 \\
1.96 \\
1.54 \\
1.58 \\
2.70 \\
1.93 \\
2.18\end{array}$ \\
\hline $\begin{array}{l}\text { Mn. } \\
\sigma_{d}\end{array}$ & 53.5 & $122 / 73$ & $\begin{array}{l}1.72 \\
0.105\end{array}$ & $\begin{array}{l}99.3 \\
14.61\end{array}$ & $\begin{array}{r}500.4 \\
86.97\end{array}$ & $\begin{array}{l}849.2 \\
122.68\end{array}$ & $\begin{array}{r}45.30 \\
6.28\end{array}$ & $\begin{array}{r}20.5 \\
3.05\end{array}$ & $\begin{array}{r}11.12 \\
1.60\end{array}$ & $\begin{array}{l}2.24 \\
0.42\end{array}$ \\
\hline
\end{tabular}


TABLE II-(Continued)

\begin{tabular}{|c|c|c|c|c|c|c|c|c|c|c|}
\hline $\begin{array}{l}(1) \\
\text { Exp. } \\
\text { No. }\end{array}$ & $\begin{array}{l}(2) \\
\text { Age }\end{array}$ & $\begin{array}{c}\text { (3) } \\
\text { Blood } \\
\text { pressure }\end{array}$ & $\begin{array}{c}(4) \\
\text { Surface } \\
\text { area }\end{array}$ & $\begin{array}{c}(5) \\
\text { Standard } \\
\text { inulin } \\
\text { clearance }\end{array}$ & $\begin{array}{c}(6) \\
\text { Standard } \\
\text { diodrast } \\
\text { clearance }\end{array}$ & $\begin{array}{c}\text { (7) } \\
\text { Standard } \\
\text { effective renal } \\
\text { blood flow }\end{array}$ & $\begin{array}{c}(8) \\
\text { Standard } \\
\text { TmD }\end{array}$ & $\begin{array}{l}\text { (9) } \\
\text { Filtration } \\
\text { fraction }\end{array}$ & $\begin{array}{l}(10) \\
\frac{C l p}{T m_{D}}\end{array}$ & $\begin{array}{l}(11) \\
\frac{\mathrm{Cl}}{\mathrm{T} \mathrm{mD}_{\mathrm{D}}}\end{array}$ \\
\hline & yrs. & $m m . H g$ & sq.m. & $\begin{array}{c}\text { cc. } / \min . / 1.73 \\
\text { sq.m. }\end{array}$ & $\underset{\text { sq.m. }}{c c . / \min . / 1.73}$ & $\underset{\text { sq.m. }}{c c . / \min . / 1.73}$ & $\begin{array}{c}m g . I / m i n . / \\
1.73 \text { sq.m. }\end{array}$ & per cent & & \\
\hline
\end{tabular}

60-69 Year Age Group

\begin{tabular}{r|l|l|l|l|l|l|l|l|r|r}
\hline 4 & 61 & & 1.69 & 106.7 & 447.7 & 806.0 & 39.63 & 22.1 & 13.90 & 2.69 \\
31 & 69 & $150 / 80$ & 1.81 & 83.2 & 390.9 & 672.0 & 36.90 & 21.3 & 10.60 & 2.25 \\
58 & 62 & $140 / 85$ & 1.73 & 91.7 & 510.3 & 941.4 & 42.81 & 18.0 & 11.93 & 2.14 \\
60 & 66 & $130 / 62$ & 1.46 & 69.6 & 426.4 & 673.6 & 49.65 & 16.3 & 8.64 & 1.41 \\
62 & 64 & $138 / 82$ & 1.42 & 81.5 & 382.2 & 733.6 & 49.28 & 21.2 & 7.92 & 1.66 \\
72 & 65 & $128 / 75$ & 1.68 & 93.1 & 522.4 & 931.2 & 59.21 & 17.8 & 8.84 & 1.67 \\
110 & 66 & $152 / 74$ & 1.47 & 101.2 & 464.5 & 837.0 & 48.43 & 21.8 & 9.63 & 2.09 \\
112 & 62 & $138 / 88$ & 1.94 & 150.8 & 534.0 & 853.0 & 53.33 & 28.3 & 10.02 & 2.83 \\
114 & 67 & $132 / 68$ & 1.67 & 57.7 & 253.4 & 453.2 & 25.43 & 22.8 & 9.97 & 2.27 \\
120 & 68 & $150 / 72$ & 1.90 & 124.2 & 489.7 & 845.8 & 40.57 & 25.3 & 12.10 & 3.07 \\
\hline Mn. & 65 & $140 / 76$ & 1.68 & 96.0 & 442.1 & 774.7 & 44.52 & 21.5 & 10.36 & 2.21 \\
$\sigma_{d}$ & & & 0.141 & 25.50 & 80.25 & 139.33 & 9.07 & 3.40 & 1.73 & 0.509 \\
\hline
\end{tabular}

70-79 Year Age Group

\begin{tabular}{r|l|l|l|l|l|l|l|l|r|r|r}
\hline 13 & 77 & & 1.67 & 69.4 & 392.7 & 627.3 & 24.45 & 17.7 & 16.1 & 2.84 \\
15 & 70 & & 1.80 & 60.8 & 234.4 & 411.0 & 34.92 & 26.0 & 6.71 & 1.74 \\
25 & 72 & $148 / 85$ & 2.08 & 86.7 & 368.0 & 598.0 & 49.90 & 23.6 & 7.37 & 1.74 \\
89 & 72 & $130 / 75$ & 1.77 & 101.0 & 519.4 & 844.6 & 47.92 & 19.5 & 10.92 & 2.13 \\
141 & 78 & $140 / 65$ & 1.53 & 113.5 & 313.9 & 587.8 & 41.37 & 36.2 & 7.69 & 2.78 \\
143 & 71 & $174 / 73$ & 1.49 & 96.3 & 424.8 & 728.7 & 41.34 & 22.7 & 10.41 & 2.36 \\
144 & 74 & $140 / 84$ & 1.68 & 72.1 & 266.6 & 474.4 & 39.06 & 27.0 & 6.69 & 1.81 \\
153 & 71 & $132 / 70$ & 1.88 & 123.5 & 287.0 & 425.9 & 32.68 & 43.1 & 8.59 & 3.71 \\
200 & 71 & $144 / 70$ & 1.62 & 77.5 & 379.1 & 603.6 & 39.77 & 20.4 & 9.57 & 1.96 \\
\hline Mn. & 73 & $144 / 75$ & 1.72 & 89.0 & 354.0 & 589.0 & 39.05 & 26.24 & 9.34 & 2.34 \\
$\sigma_{d}$ & & & 0.200 & 19.87 & 83.44 & 132.66 & 7.26 & 7.876 & 2.795 & 0.624 \\
\hline
\end{tabular}

80-89 Year Age Group

\begin{tabular}{l|l|l|l|l|l|l|l|r|r|r}
\hline 17 & 80 & $128 / 70$ & 1.65 & 69.1 & 317.0 & 460.0 & 38.35 & 21.8 & 8.27 & 1.80 \\
48 & 80 & $130 / 76$ & 1.77 & 31.4 & 165.6 & 284.1 & 17.00 & 19.5 & 10.32 & 2.09 \\
52 & 87 & $152 / 70$ & 1.42 & 42.0 & 237.0 & 412.2 & 20.61 & 17.8 & 11.82 & 2.09 \\
54 & 86 & $115 / 74$ & 1.82 & 73.6 & 308.7 & 506.0 & 35.12 & 23.9 & 8.79 & 2.10 \\
59 & 86 & $150 / 75$ & 1.62 & 72.5 & 350.4 & 570.6 & 45.54 & 20.8 & 7.72 & 1.60 \\
61 & 80 & $132 / 74$ & 1.55 & 86.8 & 462.4 & 731.5 & 38.38 & 19.4 & 12.05 & 2.26 \\
63 & 80 & $168 / 85$ & 1.97 & 91.5 & 394.2 & 680.8 & 39.11 & 23.2 & 10.11 & 2.35 \\
69 & 85 & $138 / 88$ & 1.68 & 49.5 & 248.7 & 411.1 & 37.33 & 19.9 & 6.48 & 1.29 \\
70 & 87 & $118 / 70$ & 1.61 & 37.6 & 147.2 & 237.0 & 13.33 & 25.6 & 11.12 & 2.84 \\
84 & 81 & $132 / 68$ & 1.585 & 64.5 & 208.6 & 360.0 & 23.04 & 30.9 & 9.06 & 2.79 \\
88 & 83 & $144 / 76$ & 1.58 & 68.1 & 291.4 & 498.6 & 34.35 & 23.4 & 8.53 & 1.99 \\
91 & 89 & $142 / 64$ & 1.385 & 96.4 & 334.5 & 553.8 & 27.96 & 29.0 & 12.09 & 3.47 \\
\hline Mn. & 83.7 & $137 / 74$ & 1.64 & 65.3 & 288.8 & 475.4 & 30.84 & 22.9 & 9.70 & 2.22 \\
\% & & & 0.114 & 20.35 & 88.64 & 141.3 & 9.76 & 3.81 & 1.76 & 0.572 \\
\hline
\end{tabular}

Age changes in filtration fraction and ratio of clearance to $T m$. The filtration fraction $\left(\frac{\mathrm{Cl}_{\mathbf{I}}}{\mathrm{Cl}_{\mathbf{D}}}\right)$ did not change significantly between the ages of 20 and 60 (Figure 2b). Beyond the age of 60 a small but significant increase was observed. The elevated filtration fraction of the 70-79 year group may be due to sampling errors, since two aber- rantly high values occurred in this age category. The average inulin clearance per unit of $\mathrm{Tm}$ $\left(\frac{\mathrm{Cl}_{\mathrm{I}}}{\mathrm{Tm}}\right)$ remains constant between the ages of 20 and $90^{3}$ (Figure 4a and Table II, column 11). On

${ }^{3}$ A critical ratio of 0.3 was found by comparing the average value for $20-49$ year olds with that of the $70-89$ year olds. 

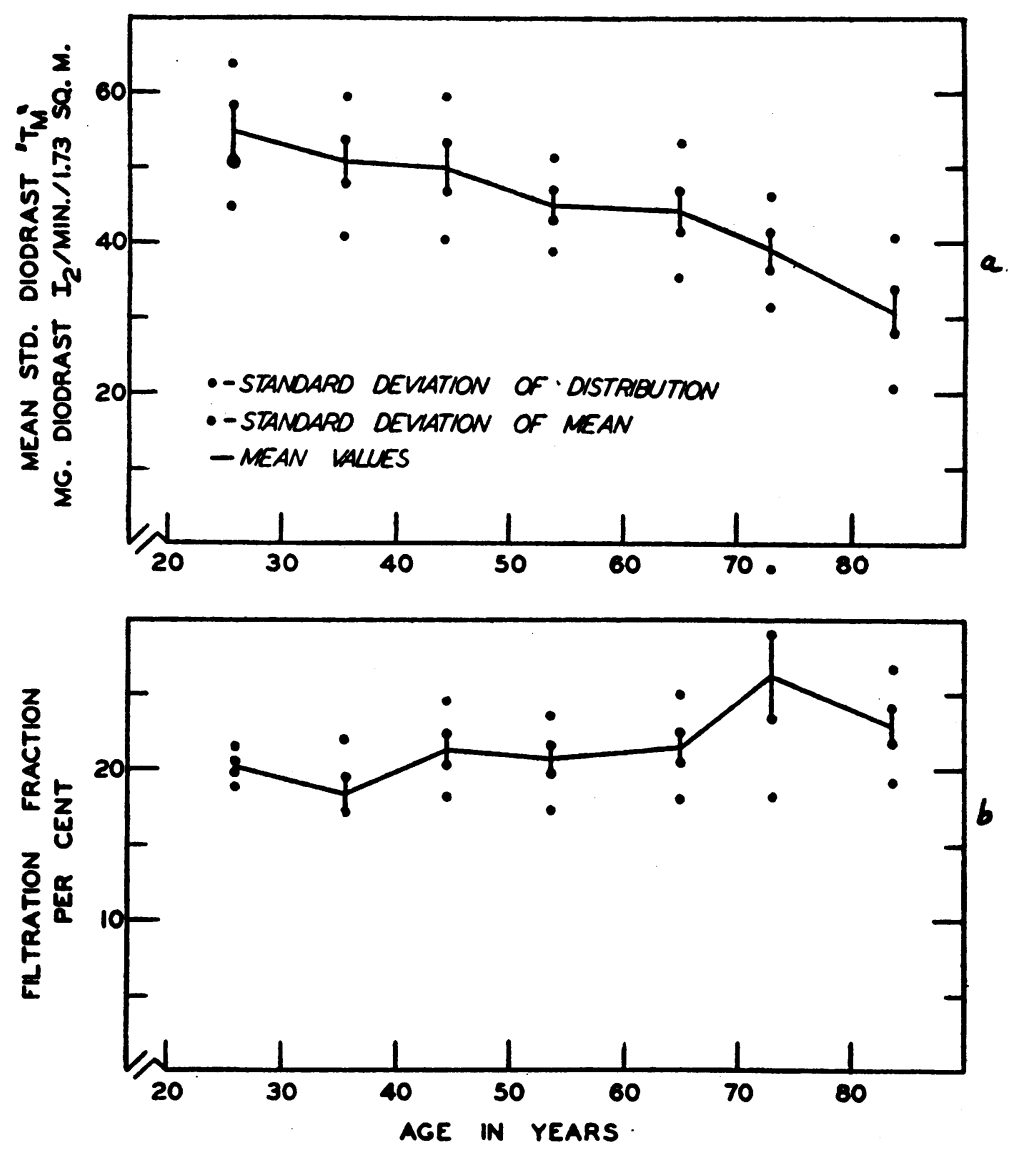

Fig. 2a. Average Change in Standard Diodrast Tm with Age, mg. Diodrast Iodine/min./1.73 sQ.M. Body Surface Area

b. Average Change in Filtration Fraction with Age, Per

Cent of Plasma Filtered

the contrary, the diodrast clearance per unit of $\mathrm{Tm}$ $\left(\frac{\mathrm{Cl}_{\mathrm{D}}}{\mathrm{Tm}}\right)$ decreases from an average value of 12.6 at age $30-39$ to 9.7 at age $80-89$ (Figure $4 \mathrm{~b}$ and Table II, column 10). The critical ratio of this difference was 4.2 ( $\mathrm{P}<1$ per cent).

\section{DISCUSSION}

The gradual reduction in renal functions observed is in accord with studies on urea clearance, blood urea nitrogen, and concentrating ability of kidneys reported by Lewis and Alving (15). The primary assumptions and supporting evidence for the interpretations of inulin clearance as a measure of rate of formation of glomerular filtrate, of diodrast clearance as a measure of effective renal plasma flow, and of diodrast $\mathrm{Tm}$ as a measure of tubular excretory capacity have been stated by Smith, Goldring and Chasis (5) and Smith (16). While the adequacy of these assumptions has been tested in young adults, there is no reason to believe that chronological age influences their validity. ${ }^{4}$

The question of whether the low $T m_{D}$ values of the older age group might have been caused by an inadequate tubular load (T.L.) of diodrast led us to study some of the same subjects at higher T.L.'s. Of the 16 subjects over 60 years of age whose T.L.'s on two tests differed by more than 15 per cent, none showed a significantly higher $T \mathrm{~m}_{\mathrm{D}}$ at the higher T.L.

4 Estimates of the extraction ratio of para amino hippuric acid have shown values of 88 to 94 per cent in normal and hypertensive subjects up to the age of 60 (17). Since PAH and diodrast are secreted by similar processes, it is improbable that increasing age results in significant changes in the extraction ratio of diodrast. 
The change observed in inulin clearance, then, may be interpreted to indicate that the glomerular filtration rate in the men 80 to 90 years of age is approximately half of that in our 20-30 year age group. To demonstrate whether or not the mean clearance remains constant between 20 and 40 would require a much larger number of subjects than the present sample. It is safe to say only that

FILTRATION FRACTION $\times 100$

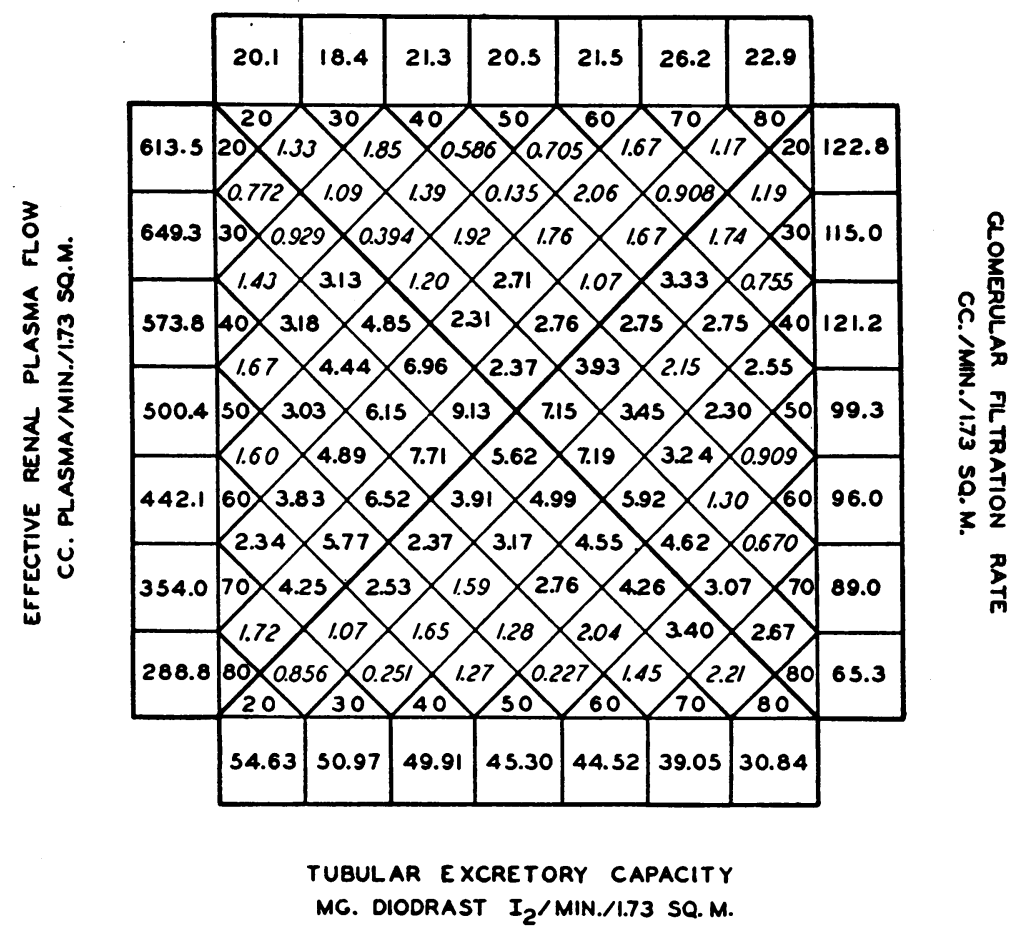

Fig. 3. Significance of Age Differences in Kidney Function

Average values by decades as follows: left-hand vertical column, effective renal plasma flow $\left(\mathrm{Cl}_{\mathrm{D}}\right) \mathrm{cc} . / \mathrm{min} . / 1.73$ sq.m.; right-hand vertical column, glomerular filtration rate $\left(\mathrm{Cl}_{1}\right)$ cc./min./1.73 sq.m.; top row, filtration fraction $\times 100\left(\frac{\mathrm{Cl}_{\mathrm{I}}}{\mathrm{Cl}_{\mathrm{D}}}\right)$; bottom row, maximum tubular excretory capacity ( Tm) for diodrast, $\mathrm{mg}$. diodrast $\mathrm{I} / \mathrm{min} . / 1.73$ sq.m. Figures in small adjacent triangles represent age decades. Figures in central squares represent critical ratios of differences between age groups indicated by intersection of the two appropriate diagonals. Values above 2.3 are significant at $\mathrm{P}=$ 5 per cent, and are shown in bold face vertical figures.

\section{Example 1.}

To find significance of the difference between the 20's and 40's for effective renal plasma flow, follow diagonally downward in the left-hand quadrant from the triangle containing the number 20 and diagonally upward from the triangle marked 40 ; these columns meet at 0.929 in slant type showing that the difference in mean values for these two age groups is not significant.

Example 2.

The critical ratio of the tubular excretory capacity ( $\mathrm{Tm}$ ) for the 30 's compared with the 80 's is found by finding the figure 30 (age) along the bottom of the figure and following its column upward to the right and diagonally upward and to the left from the triangle at the bottom of the figure marked 80. These columns meet at 4.99 shown in vertical numbers. The difference in $\mathrm{Tm}$ between the 30 - and the 80 -year-old groups is significant. 

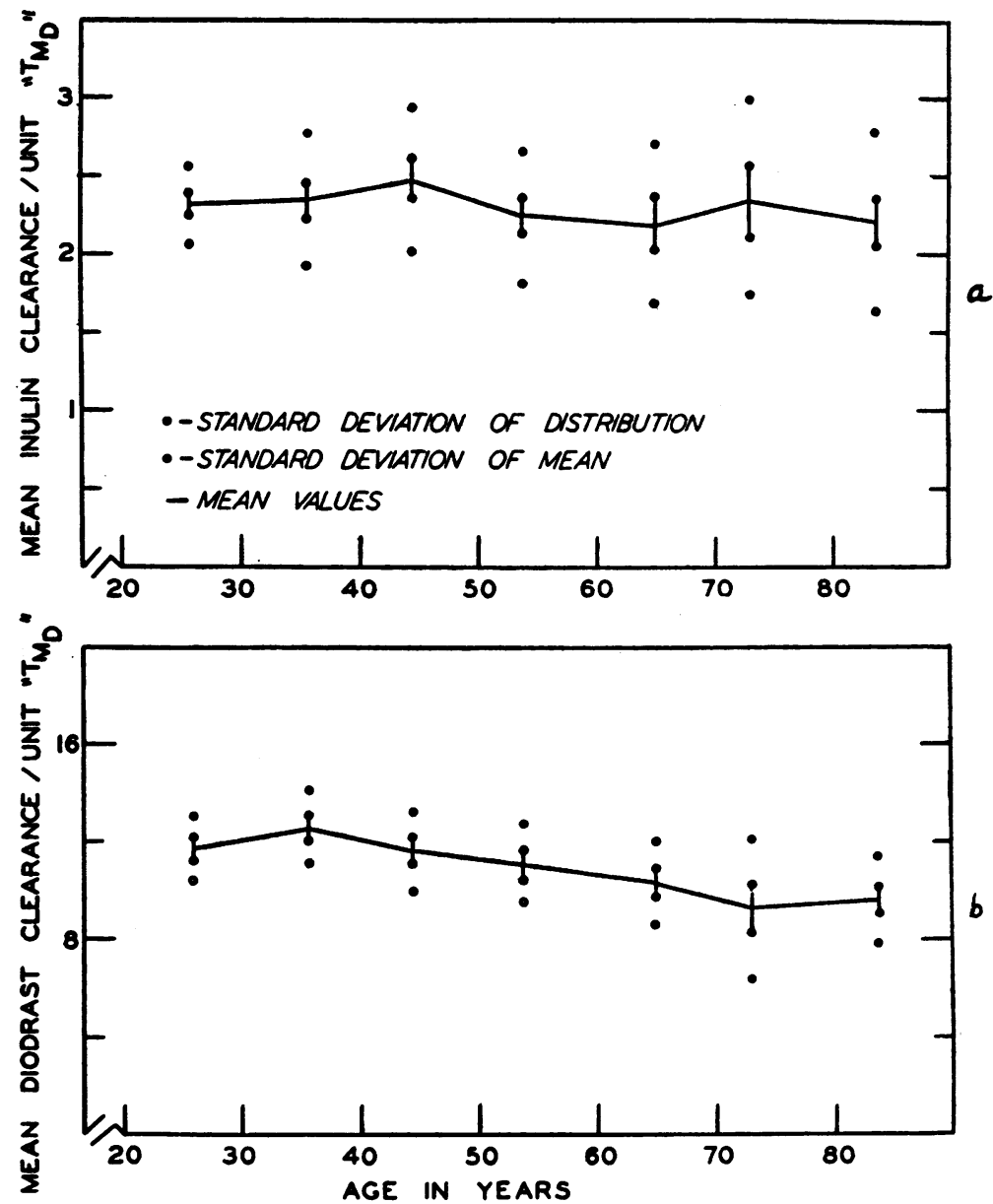

Fig. 4a. Average Change in Rate of Glomerular Filtration per Unit of Diodrast TM With Age

b. Average Change in Effective Renal Plasma flow per

Unit of Diodrast TM with Age

there appears to be less difference between mean values of adjacent decades in early adult life than between those of later decades. Although the data presented by Goldring and his colleagues (3) have values generally higher than the present series (see Table III) when analyzed by age groups, the mean $\mathrm{Cl}_{\mathrm{I}}$ of the $50-60$ year age group is significantly lower than that of the third decade.

Similarly there is a decline in the effective renal plasma flow of our selected male subjects amounting to 53 per cent between the ages of 20 and 90 years. The $\mathrm{Cl}_{\mathbf{D}}$ values reported by Goldring and associates (3) are significantly higher than those of the present group in the third decade (Critical Ratio $=3.55)$, fifth decade (C.R: $=2.79)$, and the sixth decade $($ C.R. $=2.41)$. However, the mean value for the 50-59 year group is significantly lower than that for the 20-29 year group in the New York subjects as well as in the Baltimore group.

The change in tubular excretory capacity (Figure $2 \mathrm{a}$ ) from a mean value of $54.6 \mathrm{mg}$. diodrast iodine per minute in the 20-29 year age group down to $30.8 \mathrm{mg}$. in the 80-89 year group suggests an earlier initial decrease but a gentler slope than was observed for effective renal plasma flow. The differences between the mean values for the two extremes of the age span studied are highly significant but somewhat less significant than for analogous decades of inulin and diodrast clearances. For this function a straight line easily fits between the points representing plus or minus one standard 
TABLE III

Renal functions of normal males from Smith-Goldring combined series compared with present studies

\begin{tabular}{|c|c|c|c|c|c|c|c|}
\hline \multirow{2}{*}{ Age } & \multicolumn{4}{|c|}{ Mean values calculated from literature* } & \multicolumn{3}{|c|}{ Present series } \\
\hline & & $\begin{array}{c}\text { Inulin } \\
\text { clearance }\end{array}$ & $\begin{array}{l}\text { Diodrast } \\
\text { clearance }\end{array}$ & TmD & $\begin{array}{c}\text { Inulin } \\
\text { clearance }\end{array}$ & $\begin{array}{l}\text { Diodrast } \\
\text { clearance }\end{array}$ & Tm $\mathbf{D}$ \\
\hline $\begin{array}{c}\text { years } \\
20-29\end{array}$ & $\begin{array}{r}\text { Mn. } \\
\text { n. } \\
\sigma_{d}\end{array}$ & $\begin{array}{c}c c . / \text { min./ } \\
1.73 \text { sq.m. } \\
133.3 \\
(12) \\
25.8\end{array}$ & $\begin{array}{c}c c . / \text { min./ } \\
1.73 \text { sq.m. } \\
794.5 \\
(11) \\
137.9\end{array}$ & $\begin{array}{c}\text { mg.I/min/ } \\
1.73 \text { sq.m. } \\
58.9 \\
(6) \\
6.34\end{array}$ & $\begin{array}{c}c c . / \min . / \\
1.73 \text { sq.m. } \\
122.8 \\
(9) \\
16.4\end{array}$ & $\begin{array}{c}c c . / \text { min./ } \\
1.73 \text { sg.m. } \\
613.5 \\
(9) \\
74.6\end{array}$ & $\begin{array}{c}\text { mg.I/min./ } \\
1.73 \text { sq.m. } \\
54.6 \\
(9) \\
9.49\end{array}$ \\
\hline $30-39$ & $\begin{array}{c}\mathrm{Mn} . \\
\mathrm{n} . \\
\sigma_{d}\end{array}$ & $\begin{array}{c}132.4 \\
(20) \\
19.5\end{array}$ & $\begin{array}{c}687.9 \\
(16) \\
124.8\end{array}$ & $\begin{array}{c}52.1 \\
(14) \\
8.76\end{array}$ & $\begin{array}{c}115.0 \\
(9) \\
10.8\end{array}$ & $\begin{array}{c}649.3 \\
(9) \\
117.4\end{array}$ & $\begin{array}{c}51.0 \\
(9) \\
8.63\end{array}$ \\
\hline $40-49$ & $\begin{array}{r}\mathrm{Mn} . \\
\mathrm{n} . \\
\sigma_{d}\end{array}$ & $\begin{array}{c}134.1 \\
(17) \\
20.6\end{array}$ & $\begin{array}{c}710.3 \\
(16) \\
123.3\end{array}$ & $\begin{array}{c}51.2 \\
(8) \\
9.50\end{array}$ & $\begin{array}{c}121.2 \\
(10) \\
23.3\end{array}$ & $\begin{array}{c}573.8 \\
(10) \\
111.6\end{array}$ & $\begin{array}{c}49.9 \\
(10) \\
9.81\end{array}$ \\
\hline $50-59$ & $\begin{array}{r}\mathrm{Mn} . \\
\mathrm{n} . \\
\sigma_{d}\end{array}$ & $\begin{array}{c}122.9 \\
(10) \\
26.8\end{array}$ & $\begin{array}{c}612.0 \\
(10) \\
111.6\end{array}$ & $\begin{array}{c}46.3 \\
(9) \\
6.17\end{array}$ & $\begin{array}{c}99.3 \\
(11) \\
14.6\end{array}$ & $\begin{array}{c}500.4 \\
(11) \\
87.0\end{array}$ & $\begin{array}{c}45.3 \\
(11) \\
6.28\end{array}$ \\
\hline $60-69$ & $\begin{array}{c}\mathrm{Mn} . \\
\mathbf{n} . \\
\sigma_{d}\end{array}$ & & & & $\begin{array}{l}96.0 \\
(10) \\
25.5\end{array}$ & $\begin{array}{c}442.1 \\
(10) \\
80.3\end{array}$ & $\begin{array}{c}44.5 \\
(10) \\
9.07\end{array}$ \\
\hline $70-79$ & $\begin{array}{c}\text { Mn. } \\
\mathbf{n} . \\
\sigma_{d}\end{array}$ & & & & $\begin{array}{c}89.0 \\
(9) \\
19.9\end{array}$ & $\begin{array}{c}354.0 \\
(9) \\
83.4\end{array}$ & $\begin{array}{c}39.1 \\
(9) \\
7.26\end{array}$ \\
\hline $80-89$ & $\begin{array}{c}\text { Mn. } \\
\text { n. } \\
\sigma_{d}\end{array}$ & & & & $\begin{array}{l}65.3 \\
(12) \\
20.4\end{array}$ & $\begin{array}{c}288.8 \\
(12) \\
88.6\end{array}$ & $\begin{array}{c}30.8 \\
(12) \\
9.76\end{array}$ \\
\hline
\end{tabular}

$*(3,4)$.

error of the mean for each decade. Changes in glomerular filtration rate and effective renal plasma flow with age are not so clearly linear. However, with the exception of the 20-29 year group in $\mathrm{Cl}_{\mathbf{D}}$ and the 40-49 year age group in $\mathrm{Cl}_{1}$ a straight line would fall within a single standard error of the mean of each decade. Although it is improbable that a straight line would represent the true curve of age changes in these functions, it is evident that none of the three functions shows a geometric progression. ${ }^{5}$

A marked rise occurs in the filtration fraction of the 70-79 year age group over the previous

\footnotetext{
5 Regression lines calculated by the principle of least squares for these three functions have the following formulae: $\mathrm{Cl}_{\mathrm{I}}=-0.96 \mathrm{X}+153.2 ; \mathrm{Cl}_{\mathrm{D}}=-6.44 \mathrm{X}+840$; $T m_{D}=-0.40 X+66.7$; where $X$ equals age. The functions show the following correlation coefficients with age : $\mathrm{Cl}_{\mathrm{I}},-0.68 ; \mathrm{Cl}_{\mathrm{D}},-0.65 ; \mathrm{Tm}_{\mathrm{D}},-0.66$. When the regression rates were expressed as per cent decrease each year based on the value at age 20 as 100 per cent the following rates were obtained: $\mathrm{Cl}_{\mathbf{I}}, 0.722$ per cent; $\mathrm{Cl}_{\mathbf{D}}, 0.906$ per cent; $T m_{D}, 0.678$ per cent.
}

decades. The reason for this has been mentioned above as being due chiefly to the effect of two subjects, but a definite elevation does occur in the ninth decade. It is safe to assume that a number of subjects in the ninth decade could be found who have a filtration fraction no higher than that of young adults, but in the general population higher fractions may be most common because of the incidence of hypertension and heart disease. The tendency for the filtration fraction to rise in our data may be due to arteriolar sclerosis in the efferent or efferent and afferent renal arterioles.

The constancy of the ratio between the glomerular filtration rate and tubular excretory capacity over seven decades is in accord with the hypothesis that a nephron loses its function as a unit.

The steady decline in the effective renal plasma flow per unit of tubular excretory capacity beyond the fourth decade indicates that the renal tubules of men in the ninth decade are receiving a mean plasma flow of $9.17 \mathrm{cc}$. for each $\mathrm{mg}$. of dio- 
drast iodine they are able to excrete, whereas the men in their 30's receive an average of $12.6 \mathrm{cc}$./ mg. of diodrast iodine.

This decrease in effective renal plasma flow with increasing age cannot be attributed only to a reduction of total cardiac output since no estimates of cardiac output, crude as they may be, have indicated a reduction of this order of magnitude in elderly subjects (18).

Although a number of alternative hypotheses may be advanced to explain the mechanism of reduced glomerular filtration, effective renal plasma flow, and diodrast $\mathrm{Tm}$ observed in elderly subjects, we do not yet have the crucial data to decide what mechanisms are involved in the process.

\section{SUMMARY}

Measurements of inulin clearance, diodrast clearance, and diodrast Tm were made under basal conditions in 70 males between the ages of 20 and 90 years. Nine to 12 subjects were selected from each decade on the basis of medical history, physical examination, and urine analysis. All subjects were free from history or clinical evidence of renal disease, essential hypertension, cerebrovascular accident, or heart disease. All subjects were ambulatory and afebrile.

The average inulin clearance, diodrast clearance, and diodrast $\mathrm{Tm}$ decreased linearly beyond the age of 30 years. The average inulin clearance dropped from 122.8 to $65.3 \mathrm{cc} . / \mathrm{min} . / 1.73 \mathrm{sq} . \mathrm{m}$. between the ages of 20 and 90 (46 per cent). Diodrast clearance dropped from 613 to $289 \mathrm{cc}$. plasma/ min./1.73 sq.m. between the ages of 20 and 90 (53 per cent). Over the same age span, the diodrast $\mathrm{Tm}$ dropped from 54.6 to $30.8 \mathrm{mg}$. I/min./1.73 sq.m. (43.5 per cent). Filtration fraction showed a significant rise between the third and ninth decades. Inulin clearance per unit of diodrast $\mathrm{Tm}$ did not change significantly. There was a small reduction in diodrast clearance per unit of diodrast $\mathrm{Tm}$ over the age span studied. Lack of experimental evidence precludes the definition of the mechanisms for the observed changes.

\section{ACKNOWLEDGMENT}

The following rendered invaluable technical assistance during the course of this study: Frances Berg, Clifford
Grant, Margaret McCollum, Elsie Beard, Millard Starnes, Jesse Yaffa, and William Deems. Thanks are also due Mrs. Elizabeth Strawn, Mrs. Verne Nesbitt, Mrs. Maria Singleton, and Miss Georgia Proferes for nursing assistance in carrying out the tests. The assistance of Dr. J. O. Davis in carrying out some of the tests is gratefully acknowledged.

\section{BIBLIOGRAPHY}

1. Shock, N. W., Inulin diodrast, and urea clearance studies on aged human subjects. Federation Proc., $1945,4,65$.

2. Shock, N. W., Kidney function tests in aged males. Geriatrics, 1946, 1, 232.

3. Goldring, W., Chasis, H., Ranges, H. A., and Smith, H. W., Relations of effective renal blood flow and glomerular filtration to tubular excretory mass in normal man. J. Clin. Invest., 1940, 19, 739.

4. Smith, H. W., Lectures on the Kidney. University Extension Division, University of Kansas, Lawrence, Kansas, 1943.

5. Smith, H. W., Goldring, W., and Chasis, H., The measurement of the tubular excretory mass, effective blood flow, and filtration rate in the normal human kidney. J. Clin. Invest., 1938, 17, 263.

6. Robinson, S. C., and Brucer, M., Range of normal blood pressure; a statistical and clinical study of 11,383 persons. Arch. Int. Med., 1939, 64, 409.

7. Russek, H. I., Rath, M. M., Zohman, B. L., and Miller, I., The influence of age on blood pressure. A study of 5,331 white male subjects. Am. Heart J., 1946, 32, 468.

8. Alpert, L. K., A rapid method for the determination of diodrast-iodine in blood and urine. Bull. Johns Hopkins Hosp., 1941, 68, 522.

9. Harrison, H. E., A modification of the diphenylamine method for determination of inulin. Proc. Soc. Exper. Biol. \& Med., 1942, 49, 111.

10. Flox, J., Pitesky, I., and Alving, A., A direct photoelectric colorimetric method for the determination of diodrast and iodates in blood and urine. J. Biol. Chem., 1942, 142, 147.

11. Kingsley, G. R., The direct biuret method for the determination of serum proteins as applied to photoelectric and visual colorimetry. J. Lab. \& Clin. Med., 1942, 27, 840.

12. Ma, T. S., and Zuazaga, G., Micro-Kjeldahl determination of nitrogen. Ind. Eng. Chem., 1942, 14, 280.

13. Wintrobe, M. M., The volume and hemoglobin content of the red blood corpuscle. Am. J. M. Sc., 1929, 177, 513.

14. Davies, D. F., and Shock, N. W., The variability of measurement of inulin and diodrast tests of kidney function. J. Clin. Invest., 1950, 29, 491. 
15. Lewis, W. H., Jr., and Alving, A. S., Changes with age in the renal function in adult men. I. Clearance of urea. II. Amount of urea nitrogen in the blood. III. Concentrating ability of the kidneys. Am. J. Physiol., 1938, 123, 500.

16. Smith, H. W., Note on the interpretations of clearance methods in the diseased kidney. J. Clin. Invest., 1941, 20, 631 .
17. Bradley, S. E., The validity of the clearance technique in the measurement of renal blood flow in normal man and in patients with essential hypertension. Trans. First Conference on Factors Regulating Blood Pressure, Josiah Macy, Jr. Found., New York, 1947, pp. 118-123.

18. Lewis, W. H., Jr., Changes with age in the cardiac output in adult men. Am. J. Physiol., 1938, 121, 517. 